\title{
PERSPECTIVES AND ISSUES OF TEACHING “OCCUPATIONAL HEALTH AND SAFETY” FOR PHARMACEUTICAL DEPARTMENT GRADUATES
}

\author{
Л. І. Будняк, О. О. Покотило
}

\section{Тернопільський національний медичний університет імені І. Я. Горбачевського МОЗ Украӥни \\ ПЕРСПЕКТИВИ ТА ПРОБЛЕМИ ВИКЛАДАННЯ ДИСЦИПЛІНИ «ОХОРОНА ПРАЦІ В ГАЛУЗІ СТУДЕНТАМ ФАРМАЦЕВТИЧНОГО ФАКУЛЬТЕТУ}

\begin{abstract}
An important component of training a specialist in any specialty is the formation of systematic knowledge of health and safety, life protection, the legal basis of relations between employer and employee in the implementation of his rights about healthy and safe working conditions. Nowadays, there has been a sweeping trend to a significant decreasing the auditorium hours of occupational safety, that prompted us to analyze the problematic issues and the creation of prospects for improving teaching of this discipline.

The aim of the study was analysis of teaching issues, justification of the expediency and the importance of training the discipline "Occupational Health and Safety" for future specialist in Pharmacy (Industrial pharmacy) and formation of proposals about ways to improve education approaches.

The article highlights the relevance of the study of pharmaceutical department students the discipline "Occupational Health and Safety". According to the current problems and the global transition to a mixed form and e-learning in higher education establishments it's noted the importance of changes in the organization of training. The psychosomatic features of students in the transition to distance learning are analyzed.

It is established that in today's conditions the training of the future specialist with the appropriate awareness of safety situations is one of the most important areas of his professional education. For creating a systematic students' understanding and consciousness, it's necessary teaching discipline "Occupational Health and Safety" on the high scientific and technical level, with sufficient quantity of auditorium hours, applying various forms, means, techniques and innovative methods of e-learning activities with an accent on dual education. Special attention should be paid to inspection nand boosting in knowledge of regulatory and legislative acts, because of ignorance or violation of the law does not exempt a person from the responsibility.
\end{abstract}

Key words: education; occupational health and safety; e-learning; Pharmaceutical Department.

Анотація. Важливою складовою підготовки фахівця будь-якої спеціальності є формування системних знань щодо охорони праці, безпеки життєдіяльності, правових основ відносин між роботодавцем та працівником у реалізації його права на здорові та безпечні умови праці. Останнім часом чітко прослідковується тенденція до значного скорочення аудиторних годин викладання дисциплін з охорони праці, що спонукало нас до аналізу проблемних питань і формування перспектив викладання даної дисципліни.

Метою нашого дослідження було провести аналіз питань, що виникають у навчальному процесі, обгрунтувати доцільність та необхідність вивчення дисципліни «Охорона праці в галузі» майбутніми спеціалістами у галузі «Фармація (Промислова фармація)» та сформувати пропозиції щодо шляхів вдосконалення освітніх підходів.

У статті висвітлені питання актуальності вивчення випускниками фармацевтичних факультетів закладів вищої освіти дисципліни «Охорона праці в галузі». Відповідно до проблем сьогодення та глобального переходу на форми змішаного і дистанційного навчання у закладах вищої освіти, зазначено важливість змін в організації навчання. Проаналізовано психосоматичні особливості студентів при переході на дистанційну форму навчання.

(C) L. I. Budniak, O. O. Pokotylo 
Встановлено, що в умовах сьогодення підготовка майбутнього фахівця з відповідним усвідомленням ситуацій щодо безпеки $€$ одним із найважливіших напрямів його професійної підготовки. Для формування у студентів системного розуміння необхідно викладати дисципліну «Охорона праці в галузі» на високому науково-технічному рівні, з достатнім обсягом аудиторних годин незалежно від напрямків спеціальностей, застосовуючи різні форми, засоби та інноваційні методи навчальної діяльності 3 акцентом на дуальній освіті. Окрему увагу варто приділяти вивченню та аналізу нормативно-правових актів, оскільки незнання чи порушення закону не звільняє особу від відповідальності.

Ключові слова: освіта; охорона праці; дистанційне навчання; фармацевтичний факультет.

Introduction. It is obvious that the highest social values are a man, his life and health. They are given to a person at birth, and in lifetime his goal is to take care and increase these values. The widely known quotes of French philosopher and moralist Jean de La Bruyère said: "Life is what people try to save the most, but guard the least”. Even according to the 7-level hierarchy of human needs of the Pyramid of the famous American psychologist Maslow, the safety needs are at the second level and regard as one of the primary and basic necessities, while the self-actualization needs and desire for knowledge or awareness are the highest level in the hierarchy [9]. Regardless the rather average hierarchical placement of human needs, it is still logical, that without appropriate teaching, practical training on occupational safety at educational, industrial or domestic premises and ensuring proper working conditions, individuals cannot be allowed to perform their professional duties.

Occupational health and safety is an important and one of the essential components in the educational process of higher education [10]. An extremely necessary component of training a specialist in any field is the creation of systematic knowledge on labor protection, life safety, the legal basis of the relationship between employer and employee in the implementation of his right to healthy and safe working conditions [8, 10]. In accordance with the knowledge and training, a person chooses a style of behavior in daily activities and emergencies. On the one hand it should to preserve human's health or lives and on the other hand not to pose a threat to the environment [11].

The Constitution of Ukraine guarantees human rights, among which the personal safety is an integral part. However, achieving a high level of personal safety cannot be achieved autonomously, without the participation of the individual or society. Thus, the value of human life, health and its safety are mentioned in a number of acts of European law. Article 13 of Directive 89/391/EuEC emphasizes that the main responsibilities of the employee include the necessity of taking care not only of personal safety and health, but also of the safety and health of others [2]. Due to this, employees must act in accordance with the provisions of their job description, be able to properly use production equipment, technical and organizational protection systems, personal protective equipment that require appropriate professional training. Occupational safety policies in the European Union are based on preventive approaches, which are implemented through appropriate education, awareness and prevention of accidents $[3,10]$.

Occupational accidents, fires, explosions, and other negative factors lead to 20 million accidents annually, killing up to 250,000 able-bodied population [2]. It is well-known fact, that the level of injuries in industry and day-to-day existence in Ukraine is ten times higher than in the European Union. The most common causes of accidents are lack of safety awareness and negligence [8-10]. In order to prevent such negative consequences, there is a need for constant work aimed at providing future professionals with sufficient labor protection knowledge.

According to the Resolution of the Cabinet of Ministers of Ukraine № 444 dated 26.06.2013 (with addition № 143 from 26.02.2020) “On approval of the Procedure for training the population to act in emergencies" training of pharmaceutical department students was implemented based on the results of the study of the discipline "Occupational Health and Safety". For students who is educated for the specialty 226 "Pharmacy, Industrial pharmacy", branch 22 of knowledge "Health Care", for the educational qualification level "Master" with the qualification "Master of Pharmacy" it's provided the organization of knowledge, skills and abilities to ensure the required level of safety in daily activities and emergencies on the basis of state and industry acts and rules [1].

The number of topical issues of the improvement of educational programs in work safety field has become an object of study by numerous leading specialists in the education branch (O. Zaporozhets, V. Berezutskyi, V. Begun, V. Zaplatinskyi, O. Datsko, A. Romaniv, N. Paraniak etc.) [10]. However, there are the number of issues of students' personality development that remain unresolved in terms of awareness of occupational safety proficiency. During the study of the discipline, the students' development was ensured in a 
direction that allowed him to make the right decisions in critical stressful situations.

The aim of the study is analysis of teaching problems, justification of the expediency and the importance of training the discipline "Occupational Health and Safety" and formation of proposals about ways to improve education process.

Theoretical framework. The discipline "Occupational Health and Safety" belonged to the cycle of disciplines of professionally-oriented training of specialists [10].

The purpose of teaching this discipline was to form in future professionals' skills and competencies to ensure safe work, improve its conditions, taking into account the achievements of scientific and technological progress and international experience, effective management of labor protection, as well as awareness of the unity of successful professional activity in the pharmaceutical industry.

During the practical classes, students get acquainted with the basics of work safety in a pharmacy as a component of the labor protection system in the state. They studied the Law of Ukraine "On labor protection" and other legislative acts of the field. Students become acquainted with the organizational foundations of labor protection in the pharmaceutical industry, international standards of labor protection management, safety requirements and industrial sanitation. Undergraduates have learned to analyze and classify working conditions, assess the explosiveness of the object. They also acquired skills in compiling instructions, drawing up acts on the investigation of accidents and journals on labor protection and safety, conducting occupational safety training.

For mastering the teaching material, it was taken 10 hours of lectures, 30 hours of practical classes, 50 hours of independent work of students. Taking into account the limited auditorium hours, teachers need to be very careful in the selection of educational material. Methods of teaching the discipline "Occupational Health and Safety" includes a large number of different techniques, such as open communication undergraduates with the teacher in the practical and lecture classes, analysis of numerous of practical life situations, cases, multiple-choice testing, processing of educational materials for independent work by students in in the form of creative tasks (crosswords, preparation of abstract, quizzes, presentations, roleplaying educational games) and organized group and individual on-line consultations have been placed at students disposal [6, 7].
Discussing about situational issues in a practical lesson and reasoning correct answers using theoretical knowledge significantly improves the learning quality. In the process of studying the discipline students get acquainted with regulatory framework of Labor protection, State laws on compulsory state social insurance, Standard SA 8000 "Social Responsibility”, the international standard ISO 26000:2010 "Guidance on social responsibility" etc. Lecturers read the education materials with multimedia support in dialog way that contributes to the comprehensive perception of the material and its fuller take-in. Students have possibility to prepared for lectures and classes and formulate questions in advance on unclear statements, because the materials of preparation for lectures and multimedia presentations are located in the Moodle system on the Web-portal of the university.

Practical classes of the discipline "Occupational Health and Safety" were conducted in accordance with the method of "single day", according to which the full-time training is during 5 working days: one day is for lectures and four days are for practical classes (6 academic hours). The practical classes consist of follow parts: practical work and self-preparation hour - 3 hours, seminar discussion - 2 hours, written control - 1 hour [5]. There are given some topics of practical classes: fundamentals of occupational health and safety in pharmacy; safety management in the organization; injuries and diseases in the department, investigation of accidents; special sections of safety in professional activity: key measures of fire prevention for industrial sites; social insurance against accidents and occupational diseases in manufacturing.

As a result of studying the discipline "Occupational Health and Safety" the student must know: the basics of labor legislation of Ukraine; modern methods of investigation and analysis of risks, threats and dangers in the workplace and industrial facilities; the requirements of safety in the production premises; prevention the occurrence of accidents, occupational diseases and accidents at work; features of labor protection of women, youth and invalids; features of labor protection in pharmaceutical institutions; implementation of an effective separation between the functions, duties and powers of labor protection at the workplace; requirements for production facilities, technological equipment, devices and vessels operating under pressure, storage, transportation of raw materials, finished products, production waste; rules of operation of steam, hot water boilers, compressor, refrigeration units, stationary vessels operating under 
pressure, transportation of substances and materials; means and methods of fire extinguishing.

As a result of studying the discipline "Occupational Health and Safety" the student should master next skills: take measures to create safe and healthy working conditions; to conduct safety briefing; compile safety instructions; draw up journals on occupational safety; to compile job descriptions on labor protection and safety for employees of pharmacies and pharmaceutical companies; analyze and classify working conditions, properly store flammable and explosive substances.

Undergraduates were provided with methodical recommendations, materials for preparation for practical classes, test tasks for knowledge control, situational tasks and questions at practical classes. Also, when studying some topics, students could use all the regulations related to labor protection, which is available at the department. There is a credit for the discipline at the end of the term.

Nowadays, since March 2020 due to national quarantine the most medical universities has implemented e-learning for their students. Thereafter, this caused a number of difficulties and challenges to ensure an effective distance training of prospective specialists [4]. We have analyzed some problematic issues regarding the relationship between teacher and students during e-learning, for instance:

- stagnation - a student usually has no conflicts with teachers, he is jealous of the success of others, he does not care about his position in the group, however, the student is formally present at the lesson;

- passiveness - a student is almost always alone in classes and breaks, does not communicate with anyone, does not approach anyone, does not react to anything and feels fear of the teacher;

\section{List of literature}

1. Котвіцька А. Проблемні питання фармацевтичної освіти в Україні / А. Котвіцька // Аптека : еженедельник. - 2021. - № 10 (1281). - Режим доступа : https:// www.apteka.ua/article/587425.

2. Охорона праці: європейські і міжнародні стандарти та законодавство України (порівняльний аналіз) : наук.практ. посіб. : у 2-т. / [В. С. Венедіктов, В. П. Грохольский, М. І. Іншин та ін.] ; М-во юстиції України, Державний департамент з питань адаптації законодавства, Українська асоціація фахівців трудового права. - К., 2006. - T. 1. - 713 с.

3. Охорона праці у фармацевтичній галузі : навч. посіб. / О. В. Жуковіна, О. І. Зайцев, О. І. Жуковін, Г. А. Грецька. - К. : Медицина, 2009. - 432 с.
- depression - a student often has a depressed emotional state in class, he gets lost during the teacher\&apos;s remarks to his address, suffers from a nervous disorder;

- defense - a student shows his individual activity in opposition to the requirements of teachers and students [4].

Despite the fact, that the desire for distance training is not fully supported by students, the teachers help students to improve the adaptive capacity in the learning process. The distance education system Moodle (DES Moodle) are used to organize an effective distance training. Consistently teachers worked on improving the necessary educational and methodological support of the discipline, striving to achieve the acquisition of knowledge, contributed to the formation of a scientific worldview, moral, aesthetic and other personality traits.

Conclusions and Prospects for Research. Teaching the discipline "Occupational Health and Safety" by undergraduates of pharmaceutical department is necessary and relevant. It is important to form students' understanding of the significance of following the instructions on health and life occupation, rules of operation with equipment, fire safety in order to prevent accidents. It is also crucial to acquaint students with the algorithm of actions in the event of an emergency.

Despite the quite high level of teachers' skills in implementation e-learning process, the issues of the effective distance education mainly had an organizational and technical nature.

The prospects of our further research are in improvement the training program with accent at dual learning in terms of total transition educational process in higher educational establishment in online, e-learning form.

4. Судакова I. Є. Комп’ютерні технології навчання та їх вплив на психічні стани студента / I. Є. Судакова // Проблеми освіти : зб. наук. праць / Інститут інноваційних технологій і змісту освіти МОН України. - К., 2008. - Вип. 56. - С. 56-69.

5. Тригубчак О. В. Досвід викладання дисципліни «Фармакоекономіка» для студентів спеціальності «Клінічна фармація» / О. В. Тригубчак // Медична освіта. 2013. - № 1. - C. 85-87.

6. Budniak L. I. Innovative approaches for an effective distance learning the discipline "Introduction to pharmacy". Planta+ / L. I. Budniak, O. O. Pokotylo // Наука, практика та освіта : матеріали Міжнар. наук.-практ. конф. (Київ, 19 лютого 2021 р.). - 2021. - С. 547. - Ре- 
жим доступу : https://drive.google.com/file/d/1ojzXh AighAYkWQMavX1IFgS2TI8V1QQE/view.

7. Muhambetaliev S. Kh. The Introduction of Elements of Dual Education System: Experience, Problems, Prospects / S. Kh. Muhambetaliev, A. Kh. Kasymova // Indian Journal of Science and Technology. - 2016. - Vol. 9 (47). - P. 1-12. DOI: $10.17485 / \mathrm{ijst} / 2015 / \mathrm{v} 8 \mathrm{i1} / 99711$.

8. Reinhold K. The development of higher education in occupational health and safety in Estonia and selected EU countries / K. Reinhold, V. Siirak, P. Tint // Procedia-Social and Behavioral Sciences. - 2014. - Vol. 143. - P. 52-56.

\section{References}

1. Kotvitska, A. (2021). Problemni pytannia farmatsevtyc hnoi osvity v Ukraini [Problematic issues of pharmaceutical education in Ukraine]. Aptieka: Ezheniedielnik - Pharmacy: Weekly, 10 (1281). Retrieved from: https://www.apteka.ua/ article/587425 [in Ukrainian].

2. Venediktov, V.S., Hrokholskyi, V.P., \& Inshyn, M.I. (2006). Okhorona pratsi: yevropeiski i mizhnarodni standarty ta zakonodavstvo Ukrainy (porivnialnyi analiz): naukovopraktychnyi posibnyk: u 2-t [Labor protection: European and international standards and legislation of Ukraine (comparative analysis): Scientific and practical manual: in 2 volumes]. Kyiv: Ministry of Justice of Ukraine, State Department for Approximation of Legislation, Ukrainian Association of Labor Law Specialists [in Ukrainian].

3. Zhukovina, O.V., Zaitsev, O.I., Zhukovin, O.I., \& Hretska, H.A. (2009). Okhorona pratsi u farmatsevtychnii haluzi: navchalnyi posibnyk [Occupational safety in the pharmaceutical industry: a textbook]. Kyiv: Medytsyna [in Ukrainian].

4. Sudakova, I.Ye. (2008). Kompiuterni tekhnolohii navchannia ta yikh vplyv na psykhichni stany studenta [Computer-based learning technologies and their impact on the mental state of the student] Problemy osvity: zb. nauk. pr. - Problems of Education: Collection of Scient. Works. Kyiv: Institute of Innovative Technologies and Content of Education of the Ministry of Education and Science of Ukraine [in Ukrainian].

5. Trygubchak, O.V. (2013). Dosvid vykladannia dystsypliny "Farmakoekonomika" dlia studentiv spetsialnosti "Klinichna farmatsiia” [Experience of teaching the discipline
9. Smedley J. Oxford handbook of occupational health edited / J. Smedley, F. Dick, S. Sadhra. - Publisher : Oxford University Press, 2013. - 944 p.

10. Stokes H. Challenging Occupational Health and Safety Education in Schools / H. Stokes, H. Cuervo // International Journal of Learning. - 2009. - Vol. 16, Iss. 2. - P. 215-225.

11. Yildiz A. N. Evaluation of occupational health teaching sessions for final year medical students / A. N. Yildiz, N. Bilir, O. K. Caman // Saf. Health Work. - 2012. - Vol. 3, Iss. 2. - P. 123-129. - Access mode : https://doi.org/10.5491/ SHAW.2012.3.2.123.

«Pharmacoeconomics» for students majoring in «Clinical Pharmacy»]. Medychna osvita - Medical Education, 1, 85-87 [in Ukrainian].

6. Budniak, L.I., \& Pokotylo, O.O. (2021). Innovative approaches for an effective distance learning the discipline "Introduction to pharmacy". Planta+. Nauka, praktyka ta osvita: materialy Mizhnar. nauk. konf. - Science, practice and education: the Proceedings of the International Scientific and Practical Conference. Retrieved from: https:// drive.google.com/file/d/1ojzXhAighAYkWQMavX1IFgS2 TI8V1QQE/view.

7. Muhambetaliev, S.Kh., \& Kasymova, A.Kh. (2016). The introduction of elements of dual education system: Experience, problems, prospects. Indian Journal of Science and Technology, 9 (47), 1-12. DOI: 10.17485/ijst/2015/ v8i1/99711.

8. Reinhold, K., Siirak, V., \& Tint, P. (2014). The development of higher education in occupational health and safety in Estonia and selected EU countries. Procedia-Social and Behavioral Sciences, 143, 52-56.

9. Smedley, J., Dick, F., \& Sadhra, S. (2013). Oxford handbook of occupational health edited. Publisher: Oxford University Press.

10. Stokes, H., \& Cuervo, H. (2009). Challenging occupational health and safety education in schools. International Journal of Learning, 16 (2), 215-225.

11. Yildiz, A.N., Bilir, N., \& Caman, O.K. (2012). Evaluation of occupational health teaching sessions for final year medical students. Saf. Health Work, 3 (2), 123-129. Retrieved from: https://doi.org/10.5491/SHAW.2012.3.2.123. 